\title{
PORCOS, HUMANOS E LOBISOMENS NO IMAGINÁRIO RURAL: O USO \\ ESTRUTURAL DO ANIMAL COMO SÍMBOLO QUE DEFINE A \\ HUMANIDADE
}

José Wellington de Souza ${ }^{12}$

\section{Introdução}

Claude Lévi-Strauss tornou claro para os cientistas sociais, especialmente para os antropólogos, que os animais não são apenas "bons para comer" segundo a categorização da antropologia funcionalista inglesa, mas são também bons para pensar. Desde então, muito tem sido feito no sentido de perceber as utilizações simbólicas e os usos de animais para as definições de elementos da realidade humana - como moralidade e sexualidade - e como sinalizador de tipos e graus de relação de parentesco entre os humanos, conforme já observado por Durkheim (1989) e Mauss (2003). O uso de animais como símbolo totêmico ou definidor de tabu também foi tratado pelo próprio Lévi-Strauss (2008), seguido por Edmund Leach (1983), Robert Darton (1986), Clifford Geertz (1978), Andréa Osório (2010), entre outros.

Além do valor ritual dos animais, conforme destacado por Darton (1986), Geertz (1978) e Osório (2010), cabe lembrar que os animais servem para definir a própria condição da humanidade, servindo como ponto de aproximação ou distanciamento no gradiente, onde se tensionam as polaridades de natureza e cultura, o que foi demonstrado por Edmund Leach, em seu trabalho sobre a relação entre insulto verbal e categorias animais, em que o autor sobrepõe relações entre o distanciamento dos humanos em relação aos animais e o tipo de insulto que cada um representa por sua distância física e social - o que, por sua vez, relacionava-se ao tabu alimentar.

Pretendo estender esse raciocínio a comunidades rurais, ordinariamente chamadas de tradicionais, onde, em muitas situações, alguns animais são tomados como elementos significantes, dotados de um grande leque de significados. Para os moradores de origem rural que vivem na periferia semi-rural da cidade de Liberdade (MG), alguns

\footnotetext{
${ }^{1}$ Universidade Federal de Juiz de Fora, Brasil.

${ }^{2}$ Artigo baseado em análises apresentadas em dissertação de mestrado defendida no Programa de PósGraduação em Ciência da Religião, da UFJF, intitulada: Camaradas e santos: notas sobre a relação entre desagregação e magia na periferia de Liberdade-MG, sob a orientação do Professor Dr. Robert Daibert Júnior.
} 
animais servem, não apenas como referências de ofensa ou de síntese de atributos físicos e morais, mas também para pensar as variáveis da vida não controladas pelo homem. Nesse sentido, conforme alguns moradores da região afirmaram, o beija-flor, a borboleta e os pequenos besouros se configuram como signos de bom agouro, assim como uma determinada espécie de aranha, que tece teias espessas em volta dos telhados das casas, ou os marimbondos que constroem nas paredes da casa, obliquamente, seus ninhos de barro. Inversamente, são percebidos como mau agouro, o ninho circular do marimbondo, sapos e lagartos, mariposas e corujas.

Certamente, o significado desses elementos animais não poderá ser esgotado bem como é capaz de fluir para diferentes direções. Ainda assim, focarei em um sentido específico, que passa pelo prisma da religião e, mais especificamente, pelo sentido religioso que o envolve e, como entende Leach (1983), abordarei esses elementos enquanto mitos, no sentido estruturalista do termo.

Assim, é preciso perceber que muitos desses animais são referentes de fenômenos sobrenaturais apenas superficialmente compreendidos e cujo sentido talvez seja possível atingir, mesmo que superficialmente, se atentarmos para os mitos nos quais esses animais estão dispostos. Assim, por exemplo, podemos pensar na condição amaldiçoada da mula, animal que, de acordo com que se acredita na região onde foi realizada a pesquisa de campo, é incapaz de procriar devido ao fato de ter sido amaldiçoada pela Virgem Maria e marcada com um sinal em cruz sobre o lombo, por ter negado transportar a Sagrada Família em sua fuga para o Egito. Consequentemente, é a mesma mula que nas noites de quinta-feira aparece nas quaresmas como o mauassombro da mula-sem-cabeça. O mesmo pode ser dito das mariposas, consideradas bruxas, as quais, metamorfoseadas, invadem as casas nas madrugadas para se alimentarem do sangue de recém-nascidos ainda não protegidos pelo sacramento do batismo.

Outros inúmeros exemplos podem ser dados nesse sentido. Entretanto, antes que isso seja feito, é preciso traçar algumas explicações sobre a fonte dos dados que serão expostos, assim como sobre o processo etnográfico para a coleta dessas informações. 


\section{Etnografia}

Os dados que apresento neste artigo foram coletados, principalmente, durante o trabalho de campo para minha dissertação de mestrado - a qual tratou de representações mágicas sobre a realidade local (Souza, 2010), abordando temas do "catolicismo popular" ou "catolicismo rústico" (Brandão, 1983; Candido, 2003; Queiroz, 1973) - e em outras ocasiões em que pude retornar à cidade, nos últimos anos. No trabalho de campo, deparei-me com um grande número de dados, que apesar do evidente valor etnográfico, não foi possível abordar na dissertação, dadas as limitações de tempo e de condições teóricas. Esses dados se referem à representação cultural feita na região estudada sobre a condição do homem no mundo e as relações simbólicas estabelecidas entre os homens, os animais domesticados e as representações simbólico-mitológicas que se estabelecem nessa relação - problema que pretendo abordar neste trabalho.

A etnografia foi realizada entre a população de um bairro com fortes marcas de ruralidade, na periferia de Liberdade, uma cidadezinha encravada na Serra da Mantiqueira, entre o Sul de Minas Gerais e a Zona da Mata Mineira, com população estimada em pouco mais de cinco mil habitantes. O bairro em questão é denominado Ponte, lugar para onde haviam migrado várias famílias da zona rural do município, quando a cidade substituiu sua atividade baseada na economia de subsistência pela criação extensiva de gado leiteiro, especialmente após a década de 1930 com ênfase nos anos de 1950 (Souza, 2010).

Liberdade foi fundada a partir de meados do século XVII, quando bandeiras saídas de Taubaté (SP) seguiram rumo à nascente do Rio Grande em busca de ouro. Aos bandeirantes paulistas, somaram-se padres jesuítas que estabeleceram na região o culto ao Senhor Bom Jesus do Livramento, santo padroeiro que nomeou o povoamento, chamado de Livramento até a emancipação política, no final da década de 1930, recebendo, então, o nome de Liberdade (Alves, 1993).

A cidade experimentou brevemente uma parca vida econômica com a extração de ouro, em meados do século XVIII. Com o declínio dos garimpos, durante o século XIX até 1939, data da emancipação política, a cidade passou a viver, predominantemente, do que se produziam nas fazendas, unidades de produção que buscavam a autossuficiência ao máximo. No entanto, esse panorama econômico foi gradativamente transformado, ao longo do século passado, sendo a produção para o 
consumo interno das fazendas substituída pela produção de leite e derivados, por meio da criação de gado leiteiro (Alves, 1993).

Os moradores do bairro da Ponte eram, em sua grande maioria, ex-colonos e exagregados das fazendas onde se produzia para subsistência, que foram expulsos durante o processo de transição da economia de subsistência para a criação extensiva de gado e produção de leite e derivados.

Em conversas com alguns moradores, foi possível perceber a importância simbólica da relação entre homens e animais, assim como o grande valor simbólico do animal, que ocupa, no espectro do sagrado, papel central na construção da definição de humanidade. A partir do próximo tópico, procurarei expor algumas das questões sobre esse tema.

\section{Deus, o diabo e a criação do Mundo.}

Para o grupo observado, especialmente para as mulheres idosas (em geral senhoras não alfabetizadas ou semialfabetizadas), responsáveis pela transmissão de conhecimentos religiosos, a ideia de que o mundo é criação exclusivamente divina é estranha, conforme pude constatar por mais de uma vez. Há uma tradição católica popular que busca demonstrar a natureza dúbia do mundo, a qual pende entre o bem e o mal. O mito de criação do mundo poderia, então, ser resumido mais ou menos assim:

\footnotetext{
No início, Deus criou o mundo e gerou os animais. O Diabo, entretanto, tomado de inveja, pôs-se a imitar as criações divinas, criando versões distorcidas da sagrada criação. Assim, Deus criou os pássaros, e o Diabo, em uma tentativa de repetir a obra divina, acabou criando os morcegos. O mesmo se deu com o resto da criação Deus criou o peixe e, tentando imitá-lo, o Diabo criou a cobra; Deus criou o cão, e o Diabo criou o gato; Deus criou as borboletas, e o Diabo criou as mariposas (também chamadas de bruxas). Deus criou as galinhas, e o Diabo criou os patos, e assim por diante (informação verbal).
}

Essa história me foi contada pela primeira vez por uma senhora, que afirmou ter cerca de oitenta anos sem saber a idade ao certo por ter sido registrada em cartório já “menina grande”. Chamava-se D. Maria do Rosário, era ex-colona, viúva e mãe de dez filhos, "os que vingaram". D. Maria era também benzedeira que rezava em "vento virado, quebranto, cobreiro e cortava medo de criança que apesar da idade ainda não andava", além disso, era membro da Irmandade do Sagrado Coração de Jesus. Contou-

\footnotetext{
${ }^{3}$ Informação fornecida por Maria do Rosário em Liberdade-MG, em 2009.
} 
me sobre a criação do mundo, no quintal da frente da casinha onde morava, em meio às histórias dos tatus que caçara na juventude.

Da segunda vez, ouvi de um homem alcoolizado enquanto ele relatava a um dono de loja sua decisão de deixar a pinga e passar a beber apenas vinho, pois esse era criação divina enquanto aquela era criação demoníaca, como tudo no mundo dividia-se entre obra de Deus ou do Diabo. Para ilustrar seu argumento, o homem reproduziu a mesma história que me foi contada por D. Maria.

Essa elaboração nos faz pensar na animalização da figura corporal do demônio, composto por partes de animais que ele próprio teria criado, assim como na posição do homem, criado por Deus e modificado por intermédio do Demônio, em relação à totalidade da criação. Outra história coletada durante a etnografia ilustra essa retroalimentação simbólica de animais que simbolizam o mal. Segundo me contou a mesma D. Maria do Rosário ${ }^{4}$ :

\begin{abstract}
No começo do mundo, Jesus passou por uma fazenda onde se realizava um baile, em uma noite de quinta-feira, e advertiu os frequentadores do pecado que cometiam ao participarem de uma festa em um dia santo, pois logo seria meia-noite e, portanto, sexta-feira. Jesus pediu a eles que parassem com o baile e fossem para suas casas. Em resposta, eles riram e debocharam do senhor, que após o aviso deixou o lugar. Logo depois, à meia-noite, chegou à festa um jovem muito bonito e bem vestido, todo de branco e de chapéu. Ao vê-lo, todas as mulheres do baile ficaram fascinadas e passaram a noite dançando com o estranho, sem se importar em saber quem ele era, de onde viera e porque nunca tirava da cabeça o chapéu. No fim do baile, o sanfoneiro parou de tocar, o homem se sentou para descansar. Tirou o chapéu e os sapatos, diante da plateia que, naquele instante, percebeu que passara a noite toda na companhia do Diabo, ao ver no homem os chifres e os pés de pato que o chapéu e os sapatos escondiam (informação verbal) ${ }^{5}$.
\end{abstract}

Essas e muitas outras histórias foram amplamente reproduzidas no campo da etnografia. Elas pareciam cumprir uma função de organização do mundo, estabelecendo preceitos e tabus, assim como eram transmitidas como um saber necessário para a ação na vida cotidiana. Dentre todas essas histórias do universo sacro do catolicismo rústico, sobre a relação da criação do homem e dos animais, uma me apareceu central, pela sua riqueza simbólica e pelas relações que estabelece com outras histórias. Trata-se da relação dos homens com os porcos.

\footnotetext{
${ }^{4}$ Durante a dissertação decidi substituir os nomes dos moradores do bairro da Ponte envolvidos no processo de pesquisa, por nomes fictícios, como forma de protegê-los. Isso se deu pelo fato de se tratar de um trabalho que envolvia o estudo de magia e de conflitos em um bairro muito pequeno, onde as pessoas poderiam ser facilmente expostas. Mantenho as alterações aqui.

${ }^{5}$ Informação fornecida por Maria do Rosário em Liberdade-MG, em 2009.
} 


\section{Os porcos são nossos irmãos!}

O grande drama da relação entre humanos e animais, a se manifestar entre os moradores de origem rural de Liberdade, é a relação de parentesco que esses acreditam existir entre os porcos e os humanos. O parentesco entre as duas criaturas é pensado no sentido estrito do termo, uma vez que se dizia, por mais de uma boca, que os porcos são nossos irmãos. Tal afirmação não tem nada de metafórico e é percebida como algo passível de prova. "Abra um porco e verá o seu corpo", diziam alguns dos moradores mais velhos, os mesmos que foram levados pelos pais e avós, ainda crianças, para analisar a anatomia suína no dia do abate, a fim de conhecerem um pouco da anatomia humana. De acordo com o que se acredita, os porcos e os seres humanos comungariam da mesma disposição e do mesmo formato de órgãos.

Mas a analogia entre o corpo humano e o corpo suíno e o seu parentesco com os humanos trazem um dilema: se os porcos são semelhantes aos humanos, como podem os humanos comer a carne dos porcos? A resposta dada é que os porcos são irmãos dos homens, mas foram separados desse e acabam por ocupar um espaço no mundo que, por uma perspectiva estruturalista, poderíamos chamar de diametralmente oposta à posição ocupada pelos humanos. Dizem que, enquanto os humanos têm vontade de comer a carne dos porcos durante o dia, os porcos têm vontade de comer a carne humana durante a noite. Essa oposição diametral entre dia e noite, assim como a oposição entre elementos ligados ao dia ou à noite não é nova no pensamento antropológico, sendo-lhe, ao contrário, muito cara, conforme se pode ler em Durkheim e Mauss (1984). No caso da etnografia realizada, essa oposição aparece mais de uma vez. Em outra ocasião, os moradores consideraram que "o dia é dos vivos e a noite é dos mortos", o que explicaria as aparições (mal-assombradas) durante a noite, especialmente durante as "horas abertas", períodos em que o mundo dos vivos e o mundo dos mortos se tocam, por assim dizer; quando é mais propício o encontro de seres de um mundo com o outro. É em determinadas horas - às seis e às dezoito horas; ao meio-dia e à meia-noite; às três e às quinze horas - que as portas para o outro mundo estão abertas e é possível se ver ou se ouvir o mal-assombrado.

É importante ressaltar que essas horas têm conotação religiosa, já que, segundo a tradição, ao meio-dia, Jesus Cristo foi crucificado, e, às quinze horas, o horário em que Jesus teria morrido. Nesse contexto, meia-noite e três horas seriam as oposições 
simétricas desses momentos, especialmente quando se usa dizer três da tarde e não quinze horas, separando dia e noite em duas partes iguais. Dessa forma, as divisões do dia e da noite são marcadas pela determinação do sagrado e do sobrenatural, possibilitando contatos com este último.

Mas, nesse universo simbólico, os porcos teriam sido criados pelo Diabo em uma tentativa de imitar a divina criação em sua imagem e semelhança? Não é esse o caso, já que se insistindo na questão de saber a origem da irmandade desfeita, entre humanos e porcos, obtive por resposta um mito explicativo. Esse mito me foi contado por D. Maria do Rosário, enquanto ela me mostrava os dois porquinhos que criava no fundo do terreiro (como é chamado o quintal no Sul de Minas Gerais) da casa onde morava e contava da tristeza que era quando chegava a época de matá-los. Segundo D. Maria:

Quando Deus andava pelo mundo batizando as criancinhas, ele foi em direção à casa de Eva para batizar os filhos dela.

Quando a mulher viu que Cristo vinha em direção à sua casa, ela examinou seus doze filhos e percebeu que estavam sujos e nus, e que não haveria tempo de limpálos e vesti-los, antes da chegada de Nosso Senhor. Então, ela lavou e vestiu metade deles e trancou a outra metade na despensa de comida.

Cristo chegou e batizou os seis filhos de Eva e, já ia saindo da casa quando ouviu o barulho das crianças presas na despensa:

_ O que faz barulho na despensa? - pergunta, Cristo.

_ São porcos, Senhor!

_ Então, porcos serão, pela nueza dos irmãos!

Cristo sai da casa, e Eva abre a porta da despensa de onde saem os seis porquinhos em que foram transformadas as seis crianças. Daí surgem os porcos, que são nossos irmãos e dos quais nós comemos a carne (informação verbal). ${ }^{6}$

Esse mito é conhecido por praticamente todos os moradores do bairro e me foi recontado por diversas pessoas, quase sem variações, com exceção das exclamações de espanto em recontar a história, das expressões de "Creio em Deus Pai, esconjuro", ou da declaração de que a história lhes causava arrepios.

É preciso notar que a consequência dessa transformação que torna parte dos homens em porcos (animais pela ausência de batismo) é que, durante a noite, os porcos têm vontade de comer carne humana.

No entanto, o porco que é descrito como possível comedor de carne humana não é o porco comum, ainda criado no quintal de algumas casas, na periferia semiruralizada, mas o homem (gênero sempre masculino) transformado em porco. Além disso, o porco

\footnotetext{
${ }^{6}$ Informação fornecida por Maria do Rosário em Liberdade-MG, em 2009.
} 
em questão não pode comer a carne de qualquer pessoa, apenas a dos que ainda não foram batizados, apenas de crianças pagãs, assim como as que se transformaram em porcos, ao serem privadas do batismo que separou os homens dos animais. O porco antropófago é uma criatura específica, híbrido entre homem e porco, talvez um homem tomado pela animalidade de que todo ser humano está prenhe. Para o morador da periferia semiruralizada de Liberdade, essa criatura é o lobisomem.

No sistema simbólico em questão, o lobisomem aparece sob a forma suína; por ser o porco, o animal tido como oposto simétrico do humano. Ora, é do humano que "nasce" o porco; dos filhos não batizados de Eva, chamados porcos e tornados porcos pela ausência de batismo, sacramento que consagra a separação entre os "filhos de Deus" e as "criaturas de Deus".

A tênue linha que separa os filhos de Deus das criaturas de Deus é a mesma linha que separa as distinções entre natureza e cultura, ao menos em algumas sociedades. Opondo natureza e cultura, estabelecendo distinções entre humanos e animais por meio da oposição binária marcada pela instituição do batismo, o que se encaixa perfeitamente em um modelo estruturalista de análise.

Nesse quadro, aparece a crença no lobisomem, figura que, tendo valor religioso, ocupa um papel central na ritualística dessa versão do mito da criação. Antes de aprofundarmos esse assunto, é preciso esclarecer que, para a população que conta essas histórias, a besta aparece como quadrúpede de aspecto a variar entre o canino e o suíno, monstro que tem medo de fogo em vez de temer a prata e que se transforma nas sextasfeiras da quaresma em vez das transformações sob a lua cheia. O universo simbólico do cristianismo popular tomando o lugar da origem grega da licantropia também soa estranho, e o mesmo engano encobre sua origem. A licantropia não é a causa do mal, mas uma sina de causa obscura.

Com a introdução do lobisomem, fecha-se um ciclo onde o menino-porco tem como oposto simétrico o homem - porco (lobisomem), e o homem que come o porco tem por oposição o porco que come o homem, desde que se trate da carne de um recémnascido ainda não batizado, e, portanto, fora das fronteiras da humanidade, como o incircunciso entre os judeus do Velho Testamento.

Ainda sobre o Velho Testamento, somos levados a pensar a questão do tabu alimentar sobre o porco e mesmo a proibição de se tocar em seu cadáver sob o risco de se tornar impuro. Sobre a gênese dessas proibições, o já clássico Pureza e Perigo 
(1987), da antropóloga Mary Douglas, traz trecho importante sobre a relação de seres humanos e porcos. Douglas apresenta o enigma que envolve a proibição e o consumo do porco e descarta os supostos hábitos pouco higiênicos do animal como causa lógica para esse tabu. Segundo a autora, trata-se de um tabu determinado pela condição ambígua do animal, que embora seja criado como doméstico, dele se aproveita somente a carne:

\begin{abstract}
Notemos que a única razão apresentada pelo Velho Testamento para evitar o porco é a ausência dos dois traços distintivos do gado. Nada é dito sobre os seus hábitos sujos nem do facto de ele comer imundices. Como o porco não fornece leite nem couro nem lã, não existe nenhuma razão para o cevar a não ser a sua carne. E se os israelitas não criassem o porco, não conheceriam seus hábitos. Parece-me que originalmente não era visto como poluente, pela simples razão de que, enquanto javali, não pertence à classe dos antílopes, no que está em pé de igualdade com o camelo ou o damão, tal e qual como se diz no Livro (Douglas, 1987: 44).
\end{abstract}

Por sua ambiguidade, o porco deveria ser mantido à distância, sob o risco de perturbar a ordem da criação, já que não são passíveis de integração à vida social, por não fornecerem bens como lã e por não serem adaptáveis a trabalhos de tração, ao mesmo tempo em que são criados e tratados pelo homem. Segundo Douglas:

\footnotetext{
O gado, tal como a terra habitada, recebe a benção de Deus, torna-se fértil e integrase na ordem divina. O dever do lavrador é guardar esta benção. Por um lado, tem de preservar a ordem da criação. Daí a interdição que pesa sobre os híbridos, sejam eles plantas, animais ou tecidos (misturas de lã e de linho). Em certa medida, o homem estabeleceu uma aliança com a sua terra e os seus animais, da mesma maneira que Deus celebrou com ele uma aliança. Os homens respeitavam o primogénito do seu gado e obrigavam-no a cumprir o Sabá. Os bovinos são literalmente domesticados como os escravos. Para que disfrutem da benção, urge integrá-los na ordem social (Douglas, 1987: 45).
}

Tal ambiguidade suína foi mais tarde trabalhada por Edmund Leach (1983), conforme veremos adiante. Acredito que essa ambiguidade nos ajuda a pensar a validade do uso do porco (especialmente, na figura do lobisomem) como símbolo da própria ambiguidade dos moradores do bairro da Ponte.

Por meio de várias histórias obtidas no campo de pesquisa, é possível afirmar a existência da crença de um lobisomem com aspecto suíno. Relato aqui algumas das histórias que coletei, selecionadas pelo seu caráter exemplar para o argumento apresentado. 
Uma dessas histórias me foi relatada por uma senhora, D. Júlia, ainda colona e moradora de um sítio a alguns quilômetros da cidade. De baixa estatura, pés descalços e olhos bem azuis reluzindo no rosto castigado pelo Sol e pelos anos, ela me contou, apoiada em um feixe de lenha que havia trazido do mato, ter sido testemunha e vítima de lobisomem quando jovem:

\begin{abstract}
Eu morava na roça, era pajem da filha recém-nascida de uma madrinha. Tinha uns treze anos e ia sozinha ao entardecer para a casa da mulher, a uma distância considerável da minha, cumprir minha "obrigação".

Dormia na sala, numa cama de solteiro, com a criancinha, ainda pagã. A porta da tapera não tinha trinco e era escorada com uma mão de pilão.

No meio de uma noite, algo forçou a porta e acabou por abri-la. Um ser passou por ela, uma espécie de cachorro ou porco, farejando a criança recém-nascida.

Os gritos de pavor fizeram despertar a mãe da criança, que munida de um tição de lenha em chamas, adentrou pela sala, espantando a assombração.

Apavorada, deixei a casa e rumei, no escuro, para a casa de meu pai, seguida pelo meu cãozinho de estimação. Na porteira, o lobisomem me esperava. O cãozinho avançou sobre a besta, dando tempo para que eu atravessasse a cerca de arame. Corri até o terreiro da casa de meu pai, de onde o chamei. No terreiro, o lobisomem, mais uma vez, me esperava e só foi espantado pela tocha que meu pai trazia ao abrir a porta (informação verbal) ${ }^{7}$.
\end{abstract}

Outra senhora, dona de casa, rezadeira e mãe de oito filhos, D. Divina, relatoume, na pequena sala de visitas de sua casa, enquanto tomávamos café em canecas esmaltadas, que quando era criança e morava na casa dos pais, na roça $^{8}$ :

Uma velha andarina [sic] passou por minha casa pedindo pouso. Minha família a aceitou, sabendo que não se podia negar pouso, água e comida a ninguém. Ficamos na sala, em torno de uma fogueirinha de sabugos de milho que fizemos para nos aquecer, ouvindo as histórias da velha.

Numa delas, a andante contou que, certa vez, não achando pouso, foi abrigar-se numa casinha de cruzeiro, lugar onde geralmente fincavam cruzes e faziam uma casinha para rezas e terços. Durante a madrugada, uma figura suína rondou a casinha, roncando e batendo as orelhas, enquanto triturava ossos. A mulher então sacou do terço e se pôs a rezar. Como a reza não valeu, então ela tomou um fósforo e o acendeu. Ao ver a chama, o animal desapareceu (informação verbal) ${ }^{9}$.

Em outra ocasião, ouvi de D. Vilma outra história importante. Ela mudou-se para a cidade depois de se casar, tinha nove filhos - dos quais, seis eram homens e, desses, apenas um ficara na cidade, estando os outros "espalhados por esse mundão de

\footnotetext{
${ }^{7}$ Informação fornecida por Júlia em Liberdade-MG, em 2009.

${ }^{8}$ Roça no sentido local do termo refere-se a toda área rural de sitio ou fazenda, sem se referir necessariamente à área cultivada ou plantação. Nesse contexto é muito comum se ouvir frases do tipo "no tempo em que eu morava na roça".

'Informação fornecida por Divina em Liberdade-MG, em 2009.
} 
meu Deuso" [sic]. D. Vilma estava em uma roda de conversa, sentada em um banquinho em frente a sua casa, junto de uma de suas filhas e de D. Nazaré, casada com um benzedor do bairro. Era quaresma e D. Vilma contava histórias para as companheiras e para mim:

\begin{abstract}
Uma moça havia se casado e ido morar com o marido em um sítio distante da casa paterna. Numa sexta feira, durante a quaresma, já com um filho pequeno nos braços, a moça saiu com o marido para visitar o pai. Acontece que, indo a pé, eles se demoraram e escureceu no meio do caminho. Num trecho, já início de noite, o rapaz disse à esposa que esperasse por ele no trilho, porque ele precisava ir ao mato cagar, mas já voltava.

No lugar do moço, o que voltou foi um baita de um bicho, um porco preto que avançou sobre a moça. A mulher com o bebê protegeu-se sobre um cupim. O bicho investia a botes e arrancava com os dentes a baia da saia da moça, bordada de linha vermelha. Ela gritava pelo marido. Nada!

Por fim, o bicho se cansou e desapareceu no mato. Pouco tempo depois, reapareceu o marido amarrando as calças. Questionado por não atender aos gritos da esposa, inventou uma desculpa qualquer.

Continuaram a viagem sem maiores transtornos.

No dia seguinte, após o almoço, o marido gargalhou de casos contados pelo sogro. É quando a mulher viu entre seus dentes, presas, as linhas de seu vestido. Descobriu, então, o segredo do marido lobisomem.

Após o almoço, o marido adormeceu, com a cabeça sobre o colo da esposa. Ela então se aproveitou, tomou um martelo próximo por acaso e arrebentou com ele a cabeça do marido! (informação verbal). ${ }^{10}$
\end{abstract}

O elemento comum que aparece nos três casos é a criança pagã (criança-animal) perseguida pelo lobisomem (homem-animal). No caso da segunda narrativa, é preciso saber que nos cruzeiros se enterravam, sem batismo e sem registro legal, crianças nascidas mortas, abortadas ou mortas nos primeiros dias de vida, o que permitia ao lobisomem revirar as tumbas.

Essas histórias quase nunca são contadas como anedotas ou causos, sendo muitas vezes narradas entre expressões de "te esconjuro" e "creio em Deus Pai". Algumas vezes, são relatados arrepios ao se contar a história. Os casos de aparições de lobisomens e outras visagens também não se restringem ao passado; lobisomens continuam aparecendo pelo bairro.

Pouco antes da pesquisa, um lobisomem teria aparecido no bairro e a lembrança ainda se encontrava fresca na memória dos moradores. $\mathrm{O}$ caso foi o seguinte: Uma senhora, que mora sobre um barranco no bairro, viu um jovem morador descer a rua aos berros, rasgando as roupas e estrebuchando-se pelo chão, bem debaixo de sua janela. A mulher, que olhava pela fresta, disse ter visto, quando o rapaz se transformava em bicho

\footnotetext{
${ }^{10}$ Informação fornecida por Vilma em Liberdade-MG, em 2009.
} 
e seu corpo era tomado por pelos, horríveis e arrepiados. O monstro terminou por descer a rua, desaparecendo por um beco. Logo atrás, veio sua família e alguns vizinhos rezando um terço; segundo a testemunha, no intuito de "desvirar" o rapaz. Essa história também me foi contada mais de uma vez e, em uma dessas, foi acrescentado um comentário sobre o risco que a esposa e os filhos do rapaz corriam com ele, que, transformado, ficava "fora do juízo" e poderia vir a matar a mulher e os filhos.

\section{Um mundo de oposições}

A casa dos moradores do bairro da Ponte, onde essas histórias foram ouvidas, traz importantes características que ajudam a pensar melhor a oposição homem-animal e a totalidade desse drama. A casa fica, assim como a casa do colono de fazenda, cercada de mato, e o que a separa da natureza é o terreiro de terra batida, sempre conservado limpo, onde são cultivadas algumas plantas e criados alguns animais.

A casa é o refúgio humano e objeto de várias ofensivas naturais vindas do mundo sobrenatural, que existe além do terreiro. Por isso, as portas e as janelas são protegidas com estrelas de cinco pontas, pintadas a carvão, e por crucifixos de madeira. A simples aproximação de certos animais ou plantas da casa pode ser danoso para o dono do imóvel, o que faz com que esses entes sejam afastados sempre que possível.

Uma coruja piando na comunheira da casa, um cachorro cavando o terreiro em volta da casa ou uma árvore próxima ao imóvel, cujas ramagens ultrapassam o telhado ou cujas raízes se estendam por debaixo da casa, são fatores que condenam o proprietário à morte. Da mesma forma, o olhar do gato, depois de tomar seu banho, determina quem, dentre um grupo de pessoas, vai morrer primeiro.

Assim sendo, a casa permanece dividida do mato e de tudo que nele há de ameaçador. Muitas são as fronteiras estabelecidas entre os dois mundos. Assim como os animais e as plantas devem manter distância da casa, o homem deve manter distância do mato. Um ser humano jamais deve comer fora de casa, privilégio dos chamados “animais de rabo e pelo". Da mesma forma, cães e gatos, "animais de pelo", não podem ficar dentro de casa, especialmente em dias de chuva, e muito menos subir nas camas ou sofás. 
No extremo da casa, fica o mato e os animais de caça, que os moradores afirmam ser prática abandonada, devido ao policiamento florestal, mas muito frequente em tempos passados. Relatam a caça de mamíferos, como furões, gambás, capivaras, e de aves, como jacus, patos selvagens e codornas, para consumo.

Entre os extremos, fica o terreiro e é onde se cria o porco no chiqueiro - porco que, às vezes, vive solto pelo terreiro, revirando o cisco (lixo orgânico amontoado em pequenas porções em cantos do terreiro) à procura de comida, ou correndo feito cão atrás das crianças pequenas, a exemplo do Marquês de Rabicó, das histórias de Monteiro Lobato.

Sobre esse animal dual, no espaço físico e simbólico da vida rural, Leach traça aspectos importantes em seu ensaio intitulado Aspectos Antropológicos da Linguagem: Categorias Animais de Insulto Verbal (Leach, 1983). Leach primeiro apresenta o que chama sua teoria sobre o tabu:

deixe-me dar um esboço de uma teoria geral do tabu que eu acho particularmente satisfatória para o meu trabalho como antropólogo. É uma teoria que me parece estar muito bem harmonizada com os fatos psicológicos e linguísticos. Na forma em que eu a apresento aqui ela é uma "teoria do Leach", mas ela tem várias derivações óbvias, especialmente a discussão de Radcliffe-Brown sobre o valor ritual, o trabalho de Mary Douglas (ainda não publicado) sobre animais anômalos e a versão de Lévi-Strauss da dialética hegeliana-marxista na qual os elementos sagrados do mito são revelados como sendo fatores para mediar contradições (Leach, 1983: 177).

A partir disso, Leach constrói sua teoria sobre a lógica estrutural do insulto animal ao afirmar que:

Alguns animais parecem carregar um peso injusto de possibilidade de serem utilizados como insulto. É certo que o porco é um carniceiro generalizado, mas assim também é, por sua própria natureza, o cão, e não é nada racional que nós chamemos o primeiro de "nojento" enquanto tornamos o segundo um animal doméstico de estimação. Suspeito que sentimos uma espécie de culpa em relação aos porcos. Afinal, as ovelhas nos dão lã, as vacas o leite; as galinhas, ovos; mas nós criamos porcos para o único propósito de matá-los e comê-los e isto é uma coisa vergonhosa, uma vergonha que rapidamente se associa ao próprio porco. Além disso, nas condições da vida rural inglesa, o porco no seu chiqueiro de fundo de quintal era, até muito recentemente, quase um membro da casa: muito mais do que qualquer outro animal comestível. Os porcos, como os cães, eram alimentados dos restos de comida da cozinha dos seus donos humanos. Matar e comer tais sócios comensais é, sem dúvida, um sacrilégio!(Leach, 1983: 190). 
A relação ambígua do porco em relação aos seres humanos, pendente entre os extremos de natureza e cultura, entre a casa e a mata e entre criatura e criação, acabam por determinar seu lugar privilegiado de significante prenhe de significados, que trata da própria condição humana no mundo.

\section{O homem-porco}

Alguns elementos de extrema relevância, apresentados nessas narrativas, são imensamente elucidativos, ainda mais se pudermos utilizar, como fez Leach (1983), o estruturalismo linguístico para entender as histórias religiosas em questão, que supomos ter a mesma estrutura que o mito.

Se opusermos o ser humano, batizado e filho de Deus, ao animal, especialmente o porco, não batizado e criatura de Deus, temos um equilíbrio de polos opostos que acabam por determinar o humano pelo que ele não é, ou seja, não animal (não porco) e, portanto, não deve ficar sem batismo ou sujo e nu, assim como deve permanecer nas fronteiras da casa. De forma diametralmente oposta, os animais devem ficar fora de casa, sob o risco de trazerem infortúnios para os seres humanos. É preciso salientar que, nessa comunidade, o lugar dos animais é essencialmente fora de casa.

Dessa forma, temos um quadro analítico bem equiparado ao apresentado por Edmund Leach, uma vez que, para o antropólogo britânico:

As oposições binárias são intrínsecas ao processo do pensamento humano. Qualquer descrição do mundo necessita da discriminação de categorias na forma "p é o que não-p não é". Um objeto está vivo ou não está, e não se pode formular o conceito de "vivo" a não ser como o contrário de seu par, "morto". Assim, também os seres humanos são varões ou não varões, e as pessoas do sexo oposto estão disponíveis ou não como parceiros sexuais. São essas, universalmente, as mais importantes oposições em toda a experiência humana (Leach, 1983: 59).

Mas, mais do que as oposições binárias usadas pelo estruturalismo de LéviStrauss, Leach utiliza-se da teoria estrutural do mito proposta por Lévi-Strauss, segundo a qual o mito possui uma estrutura linguística, apesar de estar além das regras linguísticas por possuir uma dupla estrutura que comunga elementos sincrônicos e diacrônicos. Segundo Lévi-Strauss: 
Essa dupla estrutura, ao mesmo tempo histórica e a-histórica, explica que o mito possa simultaneamente pertencer ao âmbito da fala (e ser analisado enquanto tal) e ao da língua (na qual é formulado) e ainda apresentar, num terceiro nível, o mesmo caráter de objeto absoluto. Esse terceiro nível também possui uma natureza linguística, porém se distingue dos outros dois (Lévi-Strauss, 2012: 225).

Dessa forma, o mito não pode ser lido e entendido de forma linear, como um texto ou uma fala comum, mas necessita de uma leitura específica. Lévi-Strauss afirma que:

\begin{abstract}
$\mathrm{Na}$ verdade, postulamos que as verdadeiras unidades constitutivas do mito não são as relações isoladas, mas feixes de relações, e que é unicamente na forma de combinações desses feixes que as unidades constitutivas adquirem uma função significante. Relações que provêm do mesmo feixe podem aparecer como separadas por grandes intervalos, quando nos colocamos numa perspectiva diacrônica, mas se chegarmos a restituí-las em seu agrupamento "natural", teremos conseguido organizar o mito em função de um sistema de referência temporal de um novo tipo e que satisfaz as condições da hipótese inicial. De fato, tal sistema é bidimensional, ao mesmo tempo sincrônico e diacrônico, reunindo assim as propriedades características da "língua" e as da "fala" (Lévi-Strauss, 2012: 227).
\end{abstract}

Sendo assim, os mitos devem ser lidos em dois sentidos, à maneira de uma partitura musical, dada sua natureza dupla, simultaneamente sincrônica e diacrônica, já que

uma partitura de orquestra só faz sentido quando lida diacronicamente ao longo de um eixo (uma página depois da outra e da esquerda para a direita) mas, ao mesmo tempo, sincronicamente ao longo do outro eixo, de cima para baixo. Em outras palavras, todas as notas situadas na mesma linha vertical formam uma grande unidade constitutiva, um feixe de relações (Lévi-Strauss, 2012: 228).

Em uma forma muito simplificada da proposta de Lévi-Strauss, teríamos de entender o mito, não apenas na sua sequência, mas nos elementos que apresenta e nas oposições de sentido que possui. Assim, poderiam ser reordenados, em nosso caso, da seguinte forma:

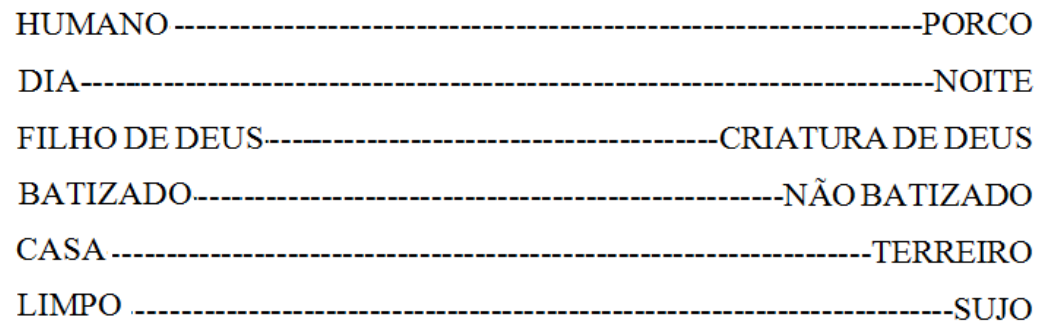


Segundo a tradição estruturalista, a oposição extrema de elementos que, na verdade, não poderiam ser de todo separados (humano-animal, em nosso caso) levaria à necessidade racional de um termo intermediário, anormal ou anômalo de equilíbrio. Nesse caso, temos como ponto intermediário o monstro, a síntese incompleta dos dois elementos, em nosso exemplo, um lobisomem com aspecto suíno.

Sobre a origem e a necessidade do monstro no universo mitológico, Leach esclarece que:

\begin{abstract}
A "mediação" (nesse sentido) é sempre alcançada com a introdução de uma terceira categoria, que é "anormal" ou "anômala" em termos das categorias "racionais" comuns. Por isso os mitos estão cheios de monstros fabulosos, deuses encarnados, mães virgens. Esse meio-termo anormal, não natural, sagrado, é tipicamente o foco de todas as práticas de tabu e de ritual. Esta abordagem de análise do mito deriva-se originalmente das técnicas da Linguística Estrutural associada ao nome de Roman Jakobson, mas deve-se mais imediatamente a Claude Lévi-Strauss. Um dos exemplos do último serve para ilustrar o "princípio geral". Certos mitos dos índios Pueblo focalizam a oposição entre a vida e a morte. Nesses mitos, encontramos uma tríplice distinção de categorias: agricultura (recurso para a vida), guerra (recurso para a morte) e caça (uma categoria mediadora, já que é um recurso para a vida do homem, mas um recurso para a morte dos animais). Outros mitos do mesmo conjunto empregam uma tríade diferente: animais que pastam (que não matam para viver), predadores (que matam para viver) e criaturas que comem carne apodrecida (mediadores, na medida em que comem carne, mas não matam para viver). Por acumulação, esse conjunto total de símbolos associados traz a implicação de que a vida e a morte não são apenas a cara e a coroa da mesma moeda, que a morte não é a consequência necessária da vida (Leach, 1983: 62-63).
\end{abstract}

Com a introdução desse terceiro elemento, temos um quadro em que o lobisomem aparece como mediador entre os estremos:

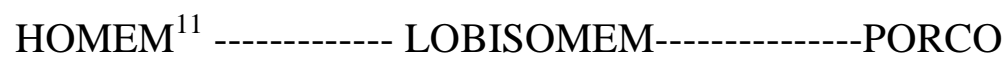

Soma-se o fato de que o lobisomem em questão não pode, a seu livre arbítrio, eviscerar vítimas que encontre ao acaso. Ele só pode devorar crianças pagãs (crianças não batizadas que, como os porcos, são criaturas, mas não filhos de Deus).

Outros dados obtidos também são relevantes para sustentar a hipótese apresentada. O primeiro diz respeito ao lugar e a forma de transformação do homem em lobisomem. Para se virar lobisomem e cumprir sua sina, o homem tem de ir até uma encruzilhada, em um lugar onde tenha se espojado um animal (burro ou porco) e tirar a

\footnotetext{
${ }^{11}$ No caso do lobisomem, o ser transformado é sempre do gênero masculino, homem-porco.
} 
roupa, deixando-a do avesso. Para se desvirar, o homem deve voltar ao mesmo lugar, antes que o galo cante pela terceira vez e vestir a roupa. Se, por acaso, alguém encontrar as roupas viradas do avesso na encruzilhada e as desvirar, a maldição do lobisomem é quebrada.

Por fim, tenho de chamar a atenção para a inegável semelhança entre a perspectiva compartilhada por humanos e porcos, no caso observado, com o primoroso trabalho de Eduardo Viveiros de Castro, em especial no que se refere ao perspectivismo ameríndio. Viveiros de Castro ensina que, segundo a filosofia ameríndia, existe um constante cultural, comungado por todos os seres, variando a perspectiva sobre a realidade, de acordo com a natureza do ser, ao contrário da filosofia ocidental em que se crê na existência de uma unidade na natureza e uma multiplicidade cultural. Nessas condições, Viveiros de Castro explica que, segundo a cosmologia ameríndia:

\begin{abstract}
Tipicamente, os humanos, em condições normais, veem os humanos como humanos e os animais como animais; quanto aos espíritos, ver estes seres usualmente invisíveis é um signo seguro de que as "condições" não são normais. Os animais predadores e os espíritos, entretanto, veem os humanos como animais de presa, ao passo que os animais de presa veem os humanos como espíritos ou como animais predadores: "O ser humano se vê a si mesmo como tal. A lua, a serpente, o jaguar e a mãe da varíola o veem contudo, como um tapir ou um pecari, que eles matam", anota Baer (1994: 224) sobre os Machiguenga. Vendo-nos como não humanos, é a si mesmos que os animais e espíritos veem como humanos. Eles se apreendem como, ou se tornam, antropomorfos quando estão em suas próprias casas ou aldeias, e experimentam seus próprios hábitos e características sob a espécie da cultura: veem seu alimento como alimento humano (os jaguares veem o sangue como cauim, os mortos veem os grilos como peixes, os urubus veem os vermes da carne podre como peixe assado etc.), seus atributos corporais (pelagem, plumas, garras, bicos etc.) como adornos ou instrumentos culturais, seu sistema social como organizado identicamente às instituições humanas (com chefes, xamãs, ritos, regras de casamento etc.). Esse "ver como" refere-se literalmente a perceptos, e não analogicamente a conceitos, ainda que, em alguns casos, a ênfase seja mais no aspecto categorial que sensorial do fenômeno; de qualquer modo, os xamãs, mestres do esquematismo cósmico (Taussig 1987: 462-63) dedicados a comunicar e administrar as perspectivas cruzadas, estão sempre aí para tornar sensíveis os conceitos ou inteligíveis as intuições (Viveiros de Castro, 2013: 242).
\end{abstract}

Isso nos leva a pensar o quanto se crê, na comunidade onde foram colhidos os relatos, que o porco possa se ver como humano a partir de sua perspectiva e o quanto os seres humanos envolvidos não acreditam que sua perspectiva sobre o mundo possa ser compartilhada por outros seres.

Entretanto, no limite de um artigo e com o material que me foi oferecido em campo, não tenho meios de levar mais adiante essa discussão, embora não possa deixar de atentar para as similaridades. 


\section{A mulher e o Porco}

Contos a respeito de punições sobrenaturais por quebra de tabu, que tem o porco como contraponto à posição humana, não se restringem a oposição ao masculino, estando também relacionados ao feminino.

Mais que isso, o porco é um símbolo que está ligado ao feminino por fazer parte de um espaço feminino, a casa e o terreiro. É o que diz Maria Isabel Dantas em sua tese, O Sabor do Sangue: uma análise sociocultural do chouriço sertanejo (Dantas, 2008), onde a autora traça o processo de criação de porcos e da fabricação do chouriço e os usos rituais e simbólicos do porco, da carne suína e, especialmente do chouriço doce feito do sangue do porco na região do Seridó.

Ao analisar a relação entre a mulher e o porco, sendo o animal criado no âmbito domestico e relegado à mulher no processo de divisão sexual do trabalho, a criação do porco é um trabalho desvalorizado e socialmente invisível, conforme Dantas (2008). A autora também atenta para fato de que quando o produto do porco, no caso o chouriço, tem valor simbólico na comunidade, este alimento é tomado como produto da ação masculina, dos chamados "mestres chouriceiros", que tomam para si a gloria do trabalho feminino que na fala do sertanejo é relegada a simples ajudante, embora seja a mulher a detentora do saber culinário em questão.

Nesse caso não é de se estranhar que o porco a mulher e o terreiro constituam elementos mitológicos ambíguos e monstruosos e que esses elementos relegados se entrecruzem social e politicamente nos terreiros ${ }^{12}$ das casas.

Por isso não devemos nos espantar de a mulher ser considerada como responsável pela transformação de homens em porco, nem do fato de a mulher se transformar, em caso específico, em porca.

Nesse caso, porém, não se trata do lobisomem, mas da mulher que, após provocar vários abortos seguidos, morre e se transforma em uma porca, eternamente seguida por sete leitõezinhos - os filhos por ela abortados e dos quais ainda tenta se livrar.

\footnotetext{
${ }^{12}$ Mais uma vez terreiro é sinônimo de quintal.
} 
Não obtive relatos muito detalhados ou mitos completos sobre a porca-dos-seteleitões, entretanto, em Geografia dos Mitos Brasileiros, Luís da Câmara Cascudo (2002) classifica as aparições como mito comum no estado de São Paulo e nas fronteiras com Minas Gerais. Cascudo também diz que:

\begin{abstract}
Quem anda a desoras ouve, pelas estradas desertas, ao derredor do cruzeiro que preside a praça, nos becos estreitos, o ronco surdo de uma porca e os insistentes grunhidos de um grupo de bacorinhos novos. Se o homem tiver coragem de voltar-se para examinar, terá justamente os segundos necessários para notar a espécie suína e a filharada roncante. Depois, leitões e porca, desaparecerão inexplicavelmente, para reaparecer e sumir-se...

Mas a visagem prefere visitar os homens casados, amigos de ocupações dispensáveis e alheias ao matrimônio. Daí haver quem a defenda e deseje a multiplicação do gênero em todas as estradas e avenidas mal iluminadas do Brasil.

Karl von den Steinen encontrou a crendice em Cuiabá noutra explicação. É o castigo aos métodos anticoncepcionais, ao aborto provocado (Cascudo, 2002: 325).
\end{abstract}

A função de manter os homens casados fora de relações extramatrimoniais não aparece entre os moradores do bairro da Ponte, mas a segunda causa, o aborto, é amplamente citada.

O caso mais detalhado que ouvi sobre a porca foi contado por D. Vilma, no mesmo dia em que ela contava sobre o lobisomem. A conversa girava em torno do tema geral das assombrações que a mulher declarava serem reais, apesar de algumas pessoas não acreditarem.

Na sequência do relato da porca, que era vista rondando a igreja, fugindo de seus filhos enjeitados, vieram outras narrativas que tinham como tema a prática de abortos.

\begin{abstract}
Antigamente, uma mulher que fez vários abortos acabou por transfigurar-se, depois de morta, em uma serpente gigante que vivia no rio. Essa serpente era tão grande, que sua cabeça ficava em Liberdade e sua cauda se estendia até a cidade vizinha de Bom Jardim de Minas.

Uma outra mulher, depois de ter abortado um grande número de filhos, ficou cega. Indo confessar-se com o padre, ela teve a visão restituída e, ao olhar para o teto da igreja, viu um grande número de crianças, semelhantes a anjos, brincando no ar e dando gargalhadas. Abismada com a beleza daquelas criaturas, ela perguntou ao padre quem elas eram. O padre disse que aquelas crianças eram todos os filhos que foram abortados pela mulher. Dito isso, ela foi privada da visão mais uma vez, como castigo por seus pecados (informação verbal) ${ }^{13}$.
\end{abstract}

As transformações em monstros por posições ambíguas ou consideradas anômalas são quase que uma constante. A mulher que rompe com o tabu do aborto é punida, sendo privada de sua humanidade e retornando ao polo animal, ocupando o

\footnotetext{
${ }^{13}$ Informação fornecida por Vilma em Liberdade-MG, em 2009.
} 
corpo de um porco ou de uma cobra (como a serpente que tentou Eva, no paraíso) ou ainda perdendo a visão. A última pena imposta pelo fratricídio lembra o caso do rei Édipo, que, ao descobrir ter desposado a mãe, fura seus olhos; aqui, temos o polo oposto do incesto, o fratricídio, conforme argumenta Leach (1983). Em nosso caso, temos uma pena similar, a perda da visão.

Mas, não só as mães que abortavam os filhos eram castigadas.

Dito isso, somos obrigados a pensar na condição ambígua da mulher na sociedade patriarcal e, mais do que isso, no papel de Eva (feminino) como responsável pela constituição da humanidade. Lembremos que, segundo o mito de divisão entre humanos e animais, o batismo, rito definidor de diferenciação entre humanidade e animalidade, foi privado a alguns dos filhos de Eva - justamente aqueles que estavam sujos e sem roupas. Poderíamos supor, a partir disso, que alguns dos filhos de Eva se transformaram em animais pelo fato de sua mãe não os ter mantidos limpos? Poderia ser dito que Eva agiu de forma inconsequente e leviana? Mais que isso, poderíamos sugerir que a transformação dos filhos de Eva em bacorinhos se deu pelo fato de ela não cuidar dos filhos e deixá-los nus? Por ser, segundo grande ofensa local, uma mulher porca ${ }^{14}$ ? São perguntas que se perdem na profundidade simbólica da estrutura do mito, embora algumas observações sobre esse assunto sejam possíveis.

Certa vez, ouvi a mesma versão do mito de Eva e os porcos, de D. Aparecida, ex-colona e ex-trabalhadora rural, aposentada à época da pesquisa. D. Aparecida me contou a história, enquanto fritava torresmos e, depois da conclusão, afirmou estar arrepiada: "Como pode uma mãe escolher quais filhos vai salvar?”. Talvez, essa afirmação e outras leituras estruturais sobre o mito digam algo também sobre Eva e sobre o lugar estrutural do feminino. Para tanto, tomemos mais uma vez um trecho de Leach, no qual ele analisa o Gênesis bíblico como um mito e demonstra a condição híbrida de Eva na estrutura mítica. Segundo Leach:

As categorias são Gado, Aves e Feras, nenhuma das quais adequada para se tornar "cônjuge" do Homem. Então Eva é finalmente tirada de uma costela de Adão... "eles são uma só carne" $(2,18-24)^{15}$.

A comparação da faixa a com a faixa $b^{16}$ nesta fase nos mostra que, na segunda estória, Eva toma o lugar das "coisas que rastejam" da primeira estória. Assim como as Coisas Rastejantes eram anômalas em relação a Peixes, Aves, Gado e Feras, também Eva é anômala dentro da oposição Homem/Animais. E, como mediação

\footnotetext{
${ }^{14}$ Ofensa dirigida a pessoa que se considera não zelar pela sua higiene ou de sua casa e filhos.

${ }^{15}$ Notação refere-se ao livro de Gênesis.

${ }^{16}$ Notação refere-se ao quadro de estrutura mitológica apresentado por Leach no texto citado.
} 
final (cap. 3), a Serpente, coisa que rasteja, é anômala dentro da oposição Homem/Mulher.

Os artistas cristãos sempre foram sensíveis a esse fato, pois conseguiam dar ao monstro uma aparência hermafrodita, ainda que indicando alguma espécie de identificação entre a Serpente e a própria Eva. Hugo Van der Góes [em A Queda, que se encontra no Kunsthistorisches Museum de Viena] coloca Eva e a Serpente na mesma pose. Miguel Ângelo faz com que tanto Adão quanto Eva fitem a Serpente em adoração, mas a Serpente tem a fisionomia de Eva.

Adão e Eva comem o fruto proibido e tornam-se conscientes da diferença sexual. A morte torna-se inevitável (3, 3-8), mas, pela primeira vez, a gravidez e a reprodução tornam-se possíveis. Eva não engravida senão depois de ter sido expulsa do Paraíso $(4,1)$ (Leach, 1983: 65).

Temos aqui a descrição da mulher como criatura ambígua, introdutora da morte e destruidora da ordem, resultado da oposição binária entre homem e animal, segundo Leach.

Por outro lado, ao menos na tradição católica, temos de considerar o papel de uma "Nova Eva" na estrutura, a qual é representada pela Virgem Maria, que, em oposição à primeira Eva, seria destituída de pecado, inclusive gerando o "Novo Adão" sem pecado.

Assim, temos uma oposição de figuras femininas, simbolizando polos da Eva e da Virgem Maria. Assim, as mulheres podem ser entendidas em uma dessas duas definições. E se uma mulher "insensata" era punida com sua transformação em animal, também era punido quem desrespeitasse a mulher sensata, santa e mãe.

Conforme ouvi de D. Maria do Rosário:

Uma criança deu um tapa nos seios da mãe enquanto era amamentado e, por isso, morreu. Indo a mãe visitar o lugar onde o filho estava enterrado, percebeu que ele mantinha para o lado de fora do túmulo um braço esticado, o mesmo com o qual tinha batido nela. Ao procurar o padre para saber o que havia acontecido e o que podia ser feito, ele esclareceu que tal fato devia-se a ela não haver punido o filho quando esse lhe deu um tapa. Mandou, então, que ela apanhasse sete varas, fosse até o cemitério e batesse na mão do filho morto até que as varas se desfizessem. Feito isso, a criança morta pôde recolher a mão (informação verbal) ${ }^{17}$.

Tal era o rigor dos castigos infligidos às crianças que infringiam tabus que, segundo D. Maria do Rosário:

Algumas crianças foram carregadas pelo "coisa-ruim" até a copa de pinheiro, por desobedecerem as mães e falarem palavras feias, e só foram tirados de lá a base de terços rezados por sua madrinha de batismo que se colocou debaixo do pinheiro com a manta usada para batizar a criança. Daí, o diabo veio, tomou a criança da copa da árvore e a entregou aos braços da madrinha. Foi o que dizem ter acontecido com

\footnotetext{
${ }^{17}$ Informação fornecida por Maria do Rosário em Liberdade-MG, em 2009.
} 
uma menina que, diante do apelo da mãe para que ela lavasse a louça, respondeu que o Diabo é que viesse lavar, pois ela não o faria. O Diabo veio, não para lavar a louça, mas para levar a menina para o alto de um pinheiro (informação verbal) ${ }^{18}$.

Temos de nos atentar para o fato de que a quebra de tabu representa uma quebra da validade do batismo, devolvendo o ser a sua condição animal (porco, cobra etc.). Ao romper seus limites de pertencimento, o ser humano se aproxima de sua condição de animal e demoníaco, sendo a criança levada pelo Demônio e só resgatada em um ritual de repetição do batismo, no qual a madrinha torna a consagrar a criança, para assim poder arrancá-la do mundo não-humano.

Tais histórias nos fazem pensar na posição simbólica ocupada pela mulher nessa sociedade, uma vez apresentadas duas situações distintas, nas quais a mulher ocupa em cada uma delas uma posição diametralmente oposta, passando de causadora e objeto do mal para a posição de redentora e reparadora do mal. Em outros termos, a mulher deixa de ser pecadora, reduzida à condição animal - ou que provoca essa redução, por sua insensatez, aos filhos - para ser a redentora capaz de trazer os humano desviado de volta da condição de animalidade, por meio do batismo da madrinha. A própria Virgem Maria é tida, no local, como "madrinha dos brasileiros". Assim, a madrinha terrestre é a mãe espiritual da criança, como o é a Virgem Santa.

Eva. Virgem Maria

Nega o batismo a seis. madrinha de órfão e abandonados.

Filhos porcos ou lobisomens Filhos e afilhados cristãos.

Faz abortos (não batizados) Não faz abortos.

Porca-dos-sete-leitões Aura de santidade.

Por fim, a Virgem, Nova Eva, ordena o mundo de acordo com sua vontade. Varias são as histórias onde se conta da passagem da Virgem pelo mundo e de como ela altera a ordem das coisas e reestrutura, ou reorganiza o mundo.

Isso se dá, por exemplo, no caso de quando a Sagrada Família fugia de seus perseguidores, quando a mulinha que levava Nossa Senhora e o Menino Jesus atolou em um lamaçal. São José tentou o mais que pode, mas não conseguiu soltá-la. Nossa Senhora saiu, então, em busca de auxílio para o seu divino esposo e encontrou um grupo

\footnotetext{
${ }^{18}$ Informação fornecida por Maria do Rosário em Liberdade-MG, em 2009.
} 
de mulheres lavando roupa na beira de um rio. Contou a elas o que se passava e pediu ajuda. As mulheres, no entanto, negaram-se a ajudar, dizendo que tinham muita roupa para lavar. Diante disso, a Virgem Maria lhes disse: "Roupa para lavar não há de lhes faltar”. Saindo dali, desesperada por ajuda, ela passou por um bar em que havia muitos homens bebendo pinga e lhes pediu ajuda. Prontamente, esses homens se dispuseram. Após terem desatolado a mula que levava a Sagrada Família, os bêbados ouviram da Virgem, em agradecimento: "pinga para beber não há de lhes faltar".

D. Maria do Rosário me contou que a mula se negou a transportar a Virgem, por isso foi amaldiçoada com a infertilidade e marca com uma cruz nas costas, estigma que todas as mulas carregam, junto da infertilidade. A jumenta, por outro lado, é um ser abençoado por ter conduzido a Sagrada Família.

\section{Considerações finais}

O porco, animal que já foi a principal fonte de proteína animal e reserva de gordura para o homem do campo, é símbolo chave na representação que se faz da condição humana perante as demais criaturas. Além disso, por sua suposta semelhança e proximidade demasiada com seus criadores humanos, torna imperativa a problematização do dilema de matar para se viver.

Espero ter conseguido demonstrar a profundidade simbólica desses elementos mitológicos presentes no catolicismo popular, bem como o uso do porco como símbolo concreto em um sistema de organização da realidade social e como forma de pensar as dualidades entre homens e animais. Meu ensejo, também, é ter demonstrado que o uso do porco como signo oposto ao homem e o monstro lobisomem como elemento conciliador de tensões lógicas expressa os arrojados meios de pensamento de populações rurais, em suas representações do mundo, e a necessidade de análises antropológicas que considerem as definições tradicionais da realidade como algo mais do que contos folclóricos ou anedóticos. 


\section{Referências}

ALVES, José Xaides de Sampaio. Serra da Mantiqueira: Liberdade transformações e permanecias. 1993. Dissertação (Mestrado em Arquitetura)-Universidade de São Paulo, São Paulo, 1993.

BRANDÃO, Carlos Rodrigues. Os caipiras de São Paulo. São Paulo: Brasiliense, 1983.

CANDIDO, Antonio. Os Parceiros do Rio Bonito: estudo sobre o caipira paulista e a transformação de seu meio de vida. São Paulo: Livraria Duas Cidades, 1977.

CASCUDO, Luís da Câmara. Geografia dos Mitos Brasileiros. São Paulo: Global, 2002.

DANTAS, Maria Isabel. O Sabor do Sangue: Uma análise sociocultural do chouriço sertanejo. Tese (Doutorado em Ciências Sociais)- Programa de Pós-Graduação em Ciências Sociais, Universidade Federal do Rio Grande do Norte, Natal, 2008.

DARNTON, Robert. O grande massacre de gatos e outros episódios da história cultural francesa. Rio de Janeiro: Graal, 1986. p. 103-139.

DOUGLAS, Mary. Pureza e perigo. Lisboa: Edições 70, 1987.

FERNANDES, Rubem César. Os cavaleiros do Bom Jesus: uma introdução às religiões populares. São Paulo: Editora Brasiliense, 1982.

FREYRE, Gilberto de Mello. Casa grande \& Senzala: introdução à história da sociedade patriarcal no Brasil. Rio de Janeiro: Record, 2001.

GEERTZ, Clifford. A interpretação das culturas. Rio de Janeiro: Zahar Editores, 1978.

LEACH, Edmund. Aspectos antropológicos da linguagem: categorias animais e insulto verbal. In: DAMATTA, Roberto (Org.). Edmund Leach. São Paulo: Ática, 1983. p. 170-198. (Coleção Grandes Cientistas Sociais).

As Ideias de Lévi-Strauss. São Paulo: Cultrix, 1973.

O gênesis enquanto um mito. In: DAMATTA, Roberto (Org.). Edmund Leach. São Paulo: Ática, 1983. p. 57-70. (Coleção Grandes Cientistas Sociais).

LÉVI-STRAUSS, Claude. Antropologia Estrutural. São Paulo: Cosac Naify, 2012.

, O Pensamento Selvagem. Campinas: Papirus, 1989.

QUEIROZ, Maria Isaura Pereira de. de. O campesinato brasileiro; ensaios sobre civilização e grupos rústicos no Brasil. São Paulo: EDUSP; Petrópolis: Vozes, 1973.

RODRIGUES, José Albertino (Org.). Durkheim (Sociologia). Trad. Laura Natal Rodrigues. $2^{\mathrm{a}}$ ed. São Paulo: Ática, 1984. (Coleção grandes cientistas sociais).

SOUZA, José W. Camaradas e santos: notas sobre a relação entre desagregação e magia na periferia de Liberdade-MG. Dissertação (Mestrado em Ciência da Religião)-Programa de Pósgraduação em Ciências da Religião, Juiz de Fora, 2010.

VIVEIROS DE CASTRO, Eduardo. A Inconstância da Alma Selvagem e Outros Ensaios de Antropologia. São Paulo: Cosac Naify, 2013.

Recebido em: 23/10/2016.

Aprovado em: 30/11/2016. 